\title{
XLIX. The effects of percussion and annealing on the magnetic moments of steel magnets
}

\section{William Brown}

To cite this article: William Brown (1887) XLIX. The effects of percussion and annealing on the magnetic moments of steel magnets, Philosophical Magazine Series 5, 23:144, 420-433, DOI: $10.1080 / 14786448708628031$

To link to this article: http://dx.doi.org/10.1080/14786448708628031

Published online: 29 Apr 2009.

Submit your article to this journal ¿

Џ Article views: 2

Q View related articles $\square$ 
3 . Course of values of the coefficient of field-magnets and armature of a dynamo.

The numbers stated in the paper may possibly be misleading, as it is not sufficiently explained that the number determined from the motion of the machine, $\left(\frac{\mathrm{R}}{8 n}\right)$, is not of the same nature as the two results of determinations made at rest, which precede.

The number determined from $\left(\frac{\mathrm{R}}{8 n}\right)$ is necessarily infinite when the current is evanescent, if there is any retention of magnetism in the machine, and diminishes continually as the current increases. The following corresponding values of this coefficient and current are given by the data referred to in the paper.

$$
\begin{aligned}
& \text { Coefficient. } \\
& \begin{array}{r}
10^{7} \times 7 \cdot 054 \\
\times 6 \cdot 250 \\
\times 5 \cdot 600 \\
\times 4 \cdot 732
\end{array}
\end{aligned}
$$

Current in amperes.

$3 \cdot 8$

$5 \cdot 5$

$7 \cdot 6$

$10 \cdot 5$

XLIX. The Effects of Percussion and Annealing on the Magnetic Moments of Steel Magnets. By William BRown, Thomson Experimental Scholar, Physical Laboratory, University of Glasgow*.

\section{PART II.}

IN Part I. of this paper, which appeared in the March I number, certain proliminary results were given, showing the effects of percussion on the magnetic moments of steel magnets. In the present communication these effects are considered in greater detail, with tables giving the results of an extended series of experiments, and the question of annealing is treated with respect to exact measurements of the annealing temperature.

The steel experimented on in this case was furnished to Sir William Thomson for experimental purposes by two different steel-makers.

The following Table gives approximately the relative percentage proportions of all the substances found in the steel, the quantities in specimen I. being taken as unity. They are taken, not from analyses of the particular pieces experimented on, but from a general analysis of the sample in each case.

* Communicated by Sir William Thomson. 
Annealing on the Magnetic Moments of Steel Magnets. 421

The proportions are on this account probably only roughly approximate, and until special analyses are obtained it seems unnecessary to give the actual quantities.

\section{TABLe I.}

Comparative Composition of the Specimens.

\begin{tabular}{|c|c|c|c|}
\hline \multirow{2}{*}{ Substance. } & \multicolumn{3}{|c|}{ Number of specimen. } \\
\hline & I. & II. & III. \\
\hline Silicon $\ldots \ldots \ldots \ldots \ldots$ & $1 \cdot 00$ & $0 \cdot 08$ & $0 \cdot 17$ \\
\hline Manganese & $1 \cdot 00$ & $1 \cdot 23$ & $3 \cdot 25$ \\
\hline Phosphorus & $1 \cdot 60$ & 1.71 & 1.55 \\
\hline Sulphur & $1 \cdot 00$ & 0.00 & $0 \cdot 00$ \\
\hline Carbon $\ldots \ldots \ldots \ldots \ldots \ldots$ & $1 \cdot 00$ & $0 \cdot 25$ & $0 \cdot 25$ \\
\hline Iron & $1 \cdot 00$ & 0.994 & 0.987 \\
\hline
\end{tabular}

All the specimens contain, as a matter of course, nearly the same amount of iron, but the other constituents differ considerably. The magnets were prepared in the same manner as those referred to in Part I. of this paper. They were all made glass-hard to begin with; and this was done by bringing them to a bright red heat, and then dropping them, with their lengths vertical, into a vessel 60 centim. deep, which was filled with water at a temperature of $7^{\circ} \mathrm{C}$.

A greater number of magnets than were actually required were prepared, but only those which were found to be straight and of uniform glass-hardness throughout, chosen for the experiments. The hardness was tested by means of a file run longitudinally along and around the magnet; in this way any marked divergence from uniformity in hardness was detected.

Also, to make sure that all the pieces of the same sample should be as nearly as possible alike, they were one by one let fall on to a block of hard wood, and those which gave the same kind of metallic ring were taken for the experiments. They were then thoroughly cleaned and polished, and their lengths, diameters, and weights accurately determined; these measurements being, for ease of reference, given below in Table II.

There were fifteen magnets in all, i.e. five samples of each specimen, and each one was made exactly 10 centimetres in lengtb. 
TABLE II.-Dimensions of Magnets.

\begin{tabular}{|r|c|c|c|c|}
\hline $\begin{array}{c}\text { Number of } \\
\text { specimen. }\end{array}$ & $\begin{array}{c}\text { Length of } \\
\text { magnet, in } \\
\text { centimetres, } \\
l .\end{array}$ & $\begin{array}{c}\text { Diameter of } \\
\text { magnet, in } \\
\text { centimetres, } \\
d .\end{array}$ & $\begin{array}{c}\text { Dimension, } \\
\text { ratio l/d. }\end{array}$ & $\begin{array}{c}\text { Weight of } \\
\text { magnet, } \\
\text { in grms. }\end{array}$ \\
\hline I. ..... & 10 & 0.300 & 33 & 5.5 \\
II. ...... & 10 & 0.265 & 38 & 4.3 \\
III...... & 10 & 0.270 & 37 & 4.5 \\
\hline
\end{tabular}

The five pieces of each sample were then magnetized by placing them between the poles of a powerful Ruhmkorff electromagnet, which was excited by a current from twentyfour Thomson tray-cells joined in series. The magnetizing current was approximately $5 \cdot 3$ amperes, producing a field of 900 C.G.S. units intensity. The field was measured by rotating a coil of known dimensions between the poles of the magnet and observing the deflection produced on a ballistic galvanometer; and this was reduced to absolute measure by comparing with the deflection (on the same galvanometer) obtained by rotating another coil of known dimensions in a field the strength of which was known.

When the field due to the electromagnet was being measured, there was nothing between the poles except the measuringcoil. In the process of magnetizing, the magnets were reversed three times between the poles of the electromagnet and then finally magnetized. This was also done in every case when the magnets were remagnetized between two sets of experiments.

After being magnetized the magnets were laid aside for a period of eighteen hours, and then the deflections were taken for the purpose of calculating their magnetic moments. They were put through the same series of operations as the magnets used in the former experiments, described in Part I.; that is to say, the deflection produced by each magnet on a magnetometer-needle was observed; each was then allowed to fall once perpendicularly through a height of 150 centimetres, with the true north end downwards, on to a thick glass plate; and the deflection on the magnetometer again taken with each magnet in exactly the same position. Each was then allowed to fall three times in succession through the same height, and the deflection again taken.

The following Table gives the results obtained for the magnets when they were all glass-hard; and also after they had been magnetized and left undisturbed for a period of eighteen hours. 
Annealing on the Magnetic Moments of Steel Magnets. 423

TABLE III.-Glass-hard.

\begin{tabular}{|c|c|c|c|c|}
\hline \multicolumn{5}{|c|}{ Specimen I. } \\
\hline \multirow{2}{*}{$\begin{array}{l}\text { Number of } \\
\text { magnet. }\end{array}$} & \multirow{2}{*}{$\begin{array}{c}\text { Magnetic } \\
\text { moment, } \\
\text { per gram. }\end{array}$} & \multicolumn{2}{|c|}{$\begin{array}{l}\text { Percentage loss due to } \\
\text { falling }\end{array}$} & \multirow{2}{*}{ Total loss. } \\
\hline & & one time. & three times. & \\
\hline 1. $\ldots . .$. & 61.08 & $0 \cdot 79$ & 0.40 & $1 \cdot 19$ \\
\hline 2. $\quad \ldots . .$. & $60 \cdot 42$ & 0.90 & $0 \cdot 20$ & $1 \cdot 10$ \\
\hline 3. $\quad \ldots . .$. & $60 \cdot 18$ & $1 \cdot 11$ & $0 \cdot 20$ & $1 \cdot 31$ \\
\hline 4. $\ldots \ldots$ & $60 \cdot 96$ & 0.49 & $0 \cdot 30$ & $0 \cdot 79$ \\
\hline 5. $\ldots \ldots$ & $59 \cdot 03$ & $1 \cdot 64$ & 0.83 & $2 \cdot 46$ \\
\hline Mean ....... & $60 \cdot 33$ & 0.99 & 0.39 & $1 \cdot 37$ \\
\hline \multicolumn{5}{|c|}{ Specimen II. } \\
\hline 1. .... & $72 \cdot 10$ & $1 \cdot 72$ & $0 \cdot 87$ & $2 \cdot 57$ \\
\hline $2 . \quad \ldots \ldots$ & $72 \cdot 70$ & $2 \cdot 13$ & $1 \cdot 30$ & $3 \cdot 53$ \\
\hline 3. $\ldots . .$. & $71 \cdot 50$ & $1 \cdot 30$ & 0.88 & $2 \cdot 16$ \\
\hline 4. ....... & $72 \cdot 70$ & $2 \cdot 13$ & 0.87 & $2 \cdot 98$ \\
\hline 5. $\ldots . .$. & $71 \cdot 80$ & $2 \cdot 15$ & $0 \cdot 88$ & 302 \\
\hline Mean ...... & $72 \cdot 16$ & $1 \cdot 88$ & 0.96 & $2 \cdot 85$ \\
\hline \multicolumn{5}{|c|}{ Specimen III. } \\
\hline 1. $\ldots . .$. & $68 \cdot 89$ & $4 \cdot 72$ & $2 \cdot 25$ & $6 \cdot 89$ \\
\hline 2. ....... & $69 \cdot 78$ & $1 \cdot 27$ & 1.72 & $2 \cdot 96$ \\
\hline 3. $\ldots . .$. & $68 \cdot 10$ & $4 \cdot 78$ & $1 \cdot 83$ & 652 \\
\hline 4. ....... & $70 \cdot 80$ & $2 \cdot 49$ & $2 \cdot 13$ & $4 \cdot 56$ \\
\hline 5. $\ldots \ldots$ & $72 \cdot 40$ & $4 \cdot 08$ & $1 \cdot 28$ & $5 \cdot 31$ \\
\hline Mean ...... & $70 \cdot 00$ & $3 \cdot 47$ & $1 \cdot 84$ & $5 \cdot 25$ \\
\hline
\end{tabular}

The above table, as far as it goes, seems to show that the percentage loss in the magnetic moment varies in the order of the quantity of manganese which the specimen contains. Thus specimen III. has a mean total loss of $5 \cdot 25$ per cent., and it has about three times as much manganese as either of the other two; and specimen II. has about 20 per cent. more manganese than I., and its loss is 3 per cent. nearly, whilst that of $I$. is approximately 1.4 per cent.

Specimen I., however, differs very much from the other specimens in the quantity of silicon it contains, and it alone contains sulphur.

These same fifteen magnets were now all fastened to a 


\section{Mr. W. Brown on the Effects of Percussion and}

piece of wood by means of soft copper wire, and annealed for one hour in a bath of linseed oil at a temperature of $100^{\circ} \mathrm{C}$.

They were then taken out and allowed to lie at the ordinary temperature of the room $\left(8^{\circ} \mathrm{C}\right.$.) for a period of 6 hours, after which they were magnetized with the same batterypower, and every precaution taken, as formerly. Then, after lying aside undisturbed for a period of 20 hours, they were put through a similar series of observations for the purpose of finding the effects of percussion in changing their magnetic moments. The results are given in the following Table:-

TABLE IV. (Annealed for one hour at $100^{\circ} \mathrm{C}$.)

\begin{tabular}{|c|c|c|c|c|}
\hline \multicolumn{5}{|c|}{ Specimen I. } \\
\hline \multirow{2}{*}{$\begin{array}{l}\text { Number of } \\
\text { magnet. }\end{array}$} & \multirow{2}{*}{$\begin{array}{l}\text { Magnetic } \\
\text { moment, } \\
\text { per gram. }\end{array}$} & \multicolumn{2}{|c|}{$\begin{array}{l}\text { Percentage loss due to } \\
\text { falling }\end{array}$} & \multirow{2}{*}{ Total loss. } \\
\hline & & one time. & three times. & \\
\hline 1. $\ldots \ldots$ & $63 \cdot 4$ & $0 \cdot 76$ & 1.92 & $2 \cdot 67$ \\
\hline 2. ... & $62 \cdot 4$ & 1.94 & $0 \cdot 39$ & $2 \cdot 32$ \\
\hline 3. ....... & $61 \cdot 7$ & 274 & $0 \cdot 60$ & $3 \cdot 33$ \\
\hline 4. $\ldots \ldots$ & $62 \cdot 6$ & 1.54 & 0.78 & $2 \cdot 70$ \\
\hline 5. & $61 \cdot 4$ & 1.97 & 1.20 & $3 \cdot 19$ \\
\hline Mean ....... & $62 \cdot 3$ & $1 \cdot 79$ & $0 \cdot 98$ & $2 \cdot 84$ \\
\hline \multicolumn{5}{|c|}{ Specimen II. } \\
\hline 1. ..... & $71 \cdot 2$ & 1.74 & $1 \cdot 33$ & $2 \cdot 67$ \\
\hline 2. ...... & $72 \cdot 1$ & $2 \cdot 57$ & $1 \cdot 32$ & $3 \cdot 86$ \\
\hline 3. ....... & $72 \cdot 1$ & $3 \cdot 43$ & $0 \cdot 89$ & $4 \cdot 29$ \\
\hline 4. $\ldots \ldots$ & 724 & $1 \cdot 71$ & $0 \cdot 87$ & $2 \cdot 56$ \\
\hline 5. ...... & $72 \cdot 4$ & $2 \cdot 99$ & 0.88 & $3 \cdot 85$ \\
\hline Mean ...... & $72 \cdot 04$ & $2 \cdot 49$ & $1 \cdot 06$ & $3 \cdot 45$ \\
\hline \multicolumn{5}{|c|}{ Specimen III. } \\
\hline 1. ........ & $66 \cdot 8$ & $2 \cdot 54$ & 0.92 & $4 \cdot 42$ \\
\hline $2 . \quad \ldots \ldots$ & $69 \cdot 8$ & $2 \cdot 54$ & $1 \cdot 74$ & $4 \cdot 24$ \\
\hline 3. $\ldots . .$. & $65 \cdot 1$ & 4.09 & $2 \cdot 37$ & $6 \cdot 36$ \\
\hline 4. ....... & $67 \cdot 4$ & $2 \cdot 63$ & $1 \cdot 80$ & $4: 38$ \\
\hline 5. & $68 \cdot 3$ & $2 \cdot 16$ & $1 \cdot 33$ & $3 \cdot 46$ \\
\hline Mean ...... & $67 \cdot 5$ & $2 \cdot 79$ & 163 & $4 \cdot 57$ \\
\hline
\end{tabular}

From the above Table we see that annealing for one hour in an oil-bath at temperature $100^{\circ} \mathrm{O}$. has slightly raised the 
magnetic moment of specimen I. and lowered it in III., whilst that of II. remains unaltered. Also that the total percentage loss in I. and II. is increased, whilst in III. it is slightly diminished; indeed, we find it is doubled in specimen l., and in II. it is increased 17 per cent., whilst it is diminished 12 per cent. in specimen III.

We must remember, however, that specimen I. alone contains sulphur, and has the least quantity of manganese, and by far the most silicon of the three, while II. contains the least amount of silicon.

The same fifteen magnets were again annealed for a period of two hours in the same oil-bath at a temperature of $100^{\circ} \mathrm{C}$. They were allowed to cool and lie for six hours, as formerly, at the ordinary temperature of the room. They were also magnetized and treated similarly in every way as in previous experiments. Then, after lying aside undisturbed for a period of twenty hours, they were put through the same series of observations for determining the loss in their magnetic moments. The results are given in the following Table:-

TABLE V.

(Annealed for two hours at $100^{\circ} \mathrm{C}$.)

\begin{tabular}{|c|c|c|c|c|}
\hline \multicolumn{5}{|c|}{ Specimen I. } \\
\hline \multirow{2}{*}{$\begin{array}{l}\text { Number of } \\
\text { magnet. }\end{array}$} & \multirow{2}{*}{$\begin{array}{l}\text { Magnetic } \\
\text { moment, } \\
\text { per grum. }\end{array}$} & \multicolumn{2}{|c|}{$\begin{array}{l}\text { Percentage loss due to } \\
\text { falling }\end{array}$} & \multirow{2}{*}{ Total loss. } \\
\hline & & one time. & three times. & \\
\hline 1. ....... & 62.09 & 1.56 & $1 \cdot 19$ & $2 \cdot 73$ \\
\hline $2 . \quad \ldots \ldots$. & 6072 & 1.99 & 1.02 & $2 \cdot 99$ \\
\hline 3. $\ldots \ldots$ & 60.72 & 1.99 & 0.61 & $2 \cdot 59$ \\
\hline 4. ....... & $62 \cdot 40$ & 1.94 & 0.39 & $2 \cdot 32$ \\
\hline 5. & $61 \cdot 20$ & $2 \cdot 37$ & $1 \cdot 21$ & 256 \\
\hline Mean ...... & $61 \cdot 42$ & 1.99 & 1.08 & $2 \cdot 84$ \\
\hline \multicolumn{5}{|c|}{ Specimen II. } \\
\hline 1. $\quad \ldots . .$. & $72 \cdot 72$ & $2 \cdot 13$ & 170 & $3 \cdot 83$ \\
\hline 2. ...... & $72 \cdot 72$ & $2 \cdot 97$ & $0 \cdot 88$ & 3.83 \\
\hline 3. & $72 \cdot 10$ & $2 \cdot 57$ & $1 \cdot 31$ & $3 \cdot 86$ \\
\hline 4. & 73.00 & $2 \cdot 96$ & 0.87 & $3 \cdot 81$ \\
\hline 5. ....... & $72 \cdot 46$ & $3 \cdot 42$ & $0-88$ & $4 \cdot 27$ \\
\hline Mean & $72 \cdot 60$ & $2 \cdot 81$ & $1 \cdot 13$ & 3.92 \\
\hline
\end{tabular}


Table V. (continued).

\begin{tabular}{|c|c|c|c|c|}
\hline \multicolumn{5}{|c|}{ Specimen III. } \\
\hline \multirow{2}{*}{$\begin{array}{l}\text { Number of } \\
\text { magnet. }\end{array}$} & \multirow{2}{*}{$\begin{array}{l}\text { Magnetic } \\
\text { moment, } \\
\text { per gram. }\end{array}$} & \multicolumn{2}{|c|}{$\begin{array}{l}\text { Percentage loss due to } \\
\text { falling. }\end{array}$} & \multirow[t]{2}{*}{ Total loss. } \\
\hline & & one time. & three times. & \\
\hline 1. ........ & $63 \cdot 86$ & $1 \cdot 85$ & 0.94 & 278 \\
\hline $2 . \ldots \ldots$ & $71 \cdot 55$ & $5 \cdot 00$ & $1 \cdot 09$ & 5.99 \\
\hline 3. $\ldots . .$. & 68.89 & $4 \cdot 72$ & $5 \cdot 40$ & $9 \cdot 87$ \\
\hline 4. $\ldots . .$. & 71.55 & $5 \cdot 00$ & $1 \cdot 74$ & $6 \cdot 61$ \\
\hline 5. $\ldots \ldots$ & $71 \cdot 25$ & $3 \cdot 32$ & $2 \cdot 14$ & $5 \cdot 39$ \\
\hline Mean ....... & $69 \cdot 42$ & 3.98 & $2 \cdot 26$ & $6 \cdot 13$ \\
\hline
\end{tabular}

From this Table we see that the second annealing for two hours has bad no effect on the magnetic moment per gramme in the case of specimens I. and II., and has only slightly increased that of specimen III. We also see that the total percentage loss is unaltered in I., and but slightly increased in II., but in specimen III. there is an increase of about 33 per cent.

All the magnets were now annealed for a period of thirty minutes in an oil-bath at a temperature of $236^{\circ} \mathrm{C}$; t they were then taken out and allowed to cool, as usual, to the ordinary temperature of the room $\left(8^{\circ} \mathrm{C}\right.$. $)$. Then, after lying aside for six hours, they were magnetized in the same manner and with the same battery-power as in the previous operations.

The temperature of the oil was at first determined approximately by means of a mercury in glass thermometer; it was, however, accurately determined by an air-thermometer constructed on a method introduced by Mr. J. T. Bottomley, and communicated by him to the Birmingham Meeting of the British Association in 1886. This method will be explained further on.

After being magnetized, the magnets were laid aside for a period of twenty hours and then put through another series of observations, the results of which are given in the following Table :- 
Annealing on the Magnetic Moments of Steel Magnets. 427

TAble VI.

(Annealed for half an hour at $236^{\circ} \mathrm{C}$.)

\begin{tabular}{|c|c|c|c|c|}
\hline \multicolumn{5}{|c|}{ Specimen I. } \\
\hline \multirow{2}{*}{$\begin{array}{l}\text { Number of } \\
\text { magnet. }\end{array}$} & \multirow{2}{*}{$\begin{array}{l}\text { Magnetic } \\
\text { moment, } \\
\text { per gram. }\end{array}$} & \multicolumn{2}{|c|}{$\begin{array}{l}\text { Percentage loss due to } \\
\text { falling }\end{array}$} & \multirow{2}{*}{ Total loss. } \\
\hline & & one time. & three times. & \\
\hline $1 . \ldots \ldots$ & $63 \cdot 48$ & $5 \cdot 14$ & $3 \cdot 21$ & $8 \cdot 19$ \\
\hline $2 . \ldots \ldots$ & $61 \cdot 90$ & $5 \cdot 27$ & 3.08 & $8 \cdot 20$ \\
\hline 3....... & $61 \cdot 60$ & $7 \cdot 45$ & $2 \cdot 96$ & $10 \cdot 20$ \\
\hline $4 . \ldots \ldots$ & $62 \cdot 90$ & 673 & 2.94 & $8 \cdot 84$ \\
\hline $5 . \ldots \ldots$ & $61 \cdot 66$ & $5 \cdot 49$ & $4 \cdot 56$ & $9 \cdot 80$ \\
\hline Mean ....... & $62 \cdot 32$ & 601 & $3 \cdot 35$ & $9 \cdot 04$ \\
\hline \multicolumn{5}{|c|}{ Specimen II. } \\
\hline 1. ........... & $69 \cdot 13$ & $6 \cdot 71$ & 4.07 & 10.51 \\
\hline 2. ........... & $69 \cdot 13$ & $7 \cdot 80$ & $7 \cdot 28$ & 14.54 \\
\hline 3. $\ldots \ldots$ & $68 \cdot 05$ & $6 \cdot 36$ & $7 \cdot 76$ & $13 \cdot 63$ \\
\hline 4. $\quad \ldots . .$. & $69 \cdot 60$ & 1377 & $2 \cdot 83$ & $16 \cdot 22$ \\
\hline 5. $\ldots \ldots$ & $68 \cdot 36$ & 1288 & 4.93 & $17 \cdot 20$ \\
\hline Mean ....... & $68 \cdot 85$ & $9 \cdot 50$ & $5 \cdot 37$ & $14 \cdot 42$ \\
\hline \multicolumn{5}{|c|}{ Specimen III. } \\
\hline 1. $\ldots \ldots$ & $65 \cdot 8$ & $17 \cdot 97$ & $4 \cdot 11$ & $21 \cdot 34$ \\
\hline 2. $\ldots \ldots$ & $67 \cdot 9$ & $10 \cdot 43$ & $5 \cdot 34$ & $15 \cdot 2 \cdot 2$ \\
\hline 3. $\ldots \ldots$ & 647 & $17 \cdot 80$ & $5 \cdot 55$ & $20 \cdot 10$ \\
\hline 4. ........ & $65 \cdot 0$ & 13.63 & $4 \cdot 21$ & $17 \cdot 27$ \\
\hline 5. $\ldots \ldots$ & $64 \cdot 0$ & 13.85 & $6 \cdot 17$ & $19 \cdot 16$ \\
\hline Mean ...... & $65 \cdot 5$ & $14 \cdot 73$ & 507 & 18.61 \\
\hline
\end{tabular}

Here we get a very interesting result: we find that, by annealing for half an hour at approximately three times the temperature, we get three times more percentage loss. It is also interesting to note that in every case the total percentage loss is almost exactly tripled; but the three specimens still preserve the same relative behaviour throughout.

The same magnets were again immersed for half an hour in 
an oil-bath at temperature $236^{\circ} \mathrm{C}$. and then allowed to cool in the air as formerly. But this time they were allowed to lie for three weeks, and then magnetized in a manner every way similar to that formerly employed. After being magnetized they lay undisturbed for a further period of twenty hours, and were then put through the same series of observations as on the previous occasions. The results are contained in the following Table :-

TABLE VII.

(Annealed for half an hour at $236^{\circ} \mathrm{C}$.)

\begin{tabular}{|c|c|c|c|c|}
\hline \multicolumn{5}{|c|}{ Specimen I. } \\
\hline \multirow{2}{*}{$\begin{array}{l}\text { Number of } \\
\text { magnet. }\end{array}$} & \multirow{2}{*}{$\begin{array}{l}\text { Magnetic } \\
\text { moment, } \\
\text { per gram. }\end{array}$} & \multicolumn{2}{|c|}{$\begin{array}{l}\text { Percentage loss due to } \\
\text { falling }\end{array}$} & \multirow{2}{*}{ Total loss. } \\
\hline & & one time. & three times. & \\
\hline 1. ........ & $57 \cdot 0$ & $7 \cdot 6$ & $7 \cdot 5$ & $14 \cdot 6$ \\
\hline 2. .......... & $60 \cdot 9$ & $12 \cdot 1$ & $5 \cdot 4$ & $16 \cdot 8$ \\
\hline 3. $\ldots . .$. & $61 \cdot 1$ & $10 \cdot 8$ & $4 \cdot 4$ & 14.8 \\
\hline 4. ....... & $60 \cdot 4$ & $8 \cdot 6$ & $5 \cdot 3$ & 136 \\
\hline 5. ....... & $60 \cdot 9$ & $15 \cdot 4$ & $5 \cdot 4$ & $19 \cdot 8$ \\
\hline Mean ....... & 60.0 & $10 \cdot 9$ & $5 \cdot 6$ & $15 \cdot 9$ \\
\hline \multicolumn{5}{|c|}{ Specimen II. } \\
\hline 1. ....... & $60 \cdot 3$ & $22 \cdot 0$ & $7 \cdot 0$ & $29 \cdot 5$ \\
\hline 2. $\quad \ldots \ldots$ & $60 \cdot 9$ & $16 \cdot 4$ & $14 \cdot 1$ & $27 \cdot 8$ \\
\hline 3. $\ldots \ldots$ & $58 \cdot 9$ & $10 \cdot 6$ & $16 \cdot 1$ & $25 \cdot 0$ \\
\hline 4. $\ldots \ldots$. & $60 \cdot 4$ & $17 \cdot 0$ & 16.9 & $31 \cdot 1$ \\
\hline $5 . \quad \ldots \ldots$ & $58 \cdot 5$ & $25 \cdot 0$ & $10 \cdot 8$ & $32 \cdot 8$ \\
\hline Mean ....... & $59 \cdot 8$ & $18 \cdot 2$ & $12 \cdot 9$ & $29 \cdot 2$ \\
\hline \multicolumn{5}{|c|}{ Specimen III. } \\
\hline 1. ....... & $56 \cdot 1$ & $16 \cdot 6$ & $9 \cdot 5$ & $24 \cdot 6$ \\
\hline 2. $\ldots \ldots$ & 56.9 & 106 & $14 \cdot 6$ & $22 \cdot 1$ \\
\hline 3. $\ldots . .$. & $56 \cdot 1$ & $17 \cdot 4$ & $9 \cdot 9$ & $25 \cdot 9$ \\
\hline 4. $\ldots \ldots$ & $58 \cdot 2$ & $23 \cdot 0$ & 6.2 & $27 \cdot 6$ \\
\hline 5. $\ldots .$. & $58 \cdot 2$ & $20 \cdot 0$ & $14 \cdot 2$ & $31 \cdot 0$ \\
\hline Mean ........ & $57 \cdot 1$ & $17 \cdot 5$ & $10 \cdot 8$ & $26 \cdot 2$ \\
\hline
\end{tabular}

We here find that the second annealing at a high tempera- 
Annealing on the Magnetic Moments of Steel Magnets. 429 ture has diminished the magnetic moment per gramme by 13 per cent. in specimen II., and by about 12 per cent. in III., whilst in specimen I. it is decreased by nearly 4 per cent. We also find that the total percentage loss due to falling four times through a height of 1.5 metre has increased above the results of the last experiment as much as 100 per cent. in specimen II., and 70 per cent. in I., and 40 per cent. in the case of specimen III.

The magnets were not again magnetized, but were allowed to lie undisturbed in the varying temperature of the room for a period of nine months, that is from May 15, 1886, till February 12, 1887. This was done merely to see what would be the effect of time upon them in their annealed condition. They were put through a similar series of observations, with the exception that they were not remagnetized. The following Table contains the results :-

\section{Table VIII.}

Magnets not remagnetized and left undisturbed for 9 months.

\begin{tabular}{|c|c|c|c|c|}
\hline \multicolumn{5}{|c|}{ Specimen I. } \\
\hline \multirow{2}{*}{$\begin{array}{l}\text { Number of } \\
\text { magnot. }\end{array}$} & \multirow{2}{*}{$\begin{array}{l}\text { Magnetic } \\
\text { moment, } \\
\text { per gram. }\end{array}$} & \multicolumn{2}{|c|}{$\begin{array}{l}\text { Percentage loss due to } \\
\text { falling }\end{array}$} & \multirow{2}{*}{ Total loss. } \\
\hline & & one time. & three times. & \\
\hline 1. $\ldots \ldots$ & $47 \cdot 79$ & $1 \cdot 02$ & 1.03 & 204 \\
\hline 2. $\ldots \ldots$ & $49 \cdot 48$ & 0.50 & 0.50 & 0.98 \\
\hline 3. $\ldots \ldots$ & $48 \cdot 51$ & 1.50 & 0.00 & 1.50 \\
\hline 4. $\ldots \ldots$ & $50 \cdot 70$ & 0.96 & $1 \cdot 45$ & $2 \cdot 40$ \\
\hline 5. $\ldots . .$. & $48 \cdot 01$ & $1 \cdot 01$ & 0.00 & 1.01 \\
\hline Mean ....... & $48 \cdot 89$ & 1.00 & 0.59 & 1.58 \\
\hline \multicolumn{5}{|c|}{ Specimen II. } \\
\hline 1. ....... & $41 \cdot 47$ & $2 \cdot 25$ & $4 \cdot 23$ & $5 \cdot 64$ \\
\hline 2. & 43.02 & $2 \cdot 89$ & $1 \cdot 50$ & 4.34 \\
\hline 3. $\ldots \ldots$ & $39 \cdot 28$ & 1.58 & 0.80 & $2 \cdot 38$ \\
\hline 4. $\ldots \ldots$ & $41 \cdot 00$ & $1 \cdot 14$ & 0.00 & $1 \cdot 14$ \\
\hline 5. $\ldots .$. & $38 \cdot 66$ & 080 & $2 \cdot 52$ & $3 \cdot 22$ \\
\hline Mean ....... & $40 \cdot 68$ & 1.73 & $1 \cdot 81$ & $3 \cdot 34$ \\
\hline
\end{tabular}


Table VIII. (continued).

\begin{tabular}{|c|c|c|c|c|}
\hline \multicolumn{5}{|c|}{ Specimen III. } \\
\hline \multirow{2}{*}{$\begin{array}{l}\text { Number of } \\
\text { magnet. }\end{array}$} & \multirow{2}{*}{$\begin{array}{c}\text { Magnetic } \\
\text { moment, } \\
\text { per gram. }\end{array}$} & \multicolumn{2}{|c|}{$\begin{array}{l}\text { Percentage loss due to } \\
\text { falling }\end{array}$} & \multirow{2}{*}{ Total loss. } \\
\hline & & one time. & three times. & \\
\hline 1. ...... & $42 \cdot 31$ & $2 \cdot 11$ & $2 \cdot 16$ & $4 \cdot 22$ \\
\hline 2. ..... & $43 \cdot 45$ & $1 \cdot 37$ & $1 \cdot 38$ & $2 \cdot 82$ \\
\hline 3. ...... & $41 \cdot 11$ & 0.00 & 0.00 & 0.00 \\
\hline 4. ....... & $41 \cdot 11$ & $1 \cdot 45$ & 1.47 & $2 \cdot 90$ \\
\hline 5. $\ldots \ldots$ & $39 \cdot 36$ & $1 \cdot 77$ & 0.77 & $2 \cdot 27$ \\
\hline Mean & $41 \cdot 46$ & $1 \cdot 34$ & $1 \cdot 15$ & $2 \cdot 44$ \\
\hline
\end{tabular}

From the above Table we find that the relative losses of magnetism in the different specimens due to lying undisturbed, as indicated by the diminished magnetic moments, is in the reverse order to what has taken place throughout the whole series when the magnets were subjected to percussion.

The total percentage loss all through these experiments due to percussion has been in the order of the number of the specimen. Thus specimen I. has always decreased the least and specimen III. the most; but, in the case of lying undisturbed for nine months, the decrease in the magnetic moment of specimen I. is 3.5 per cent., and of II. 3.7 per cent., while III. has diminished only 1.6 per cent. Specimen III., however, contains about three times as much manganese as either I. or II.

In Joule's Scientific Papers, vol. i. page 591, some results are given on the effects of time and temperature on hard magnets. The magnets used by him were either one inch long or half an inch, and were made up of a number of thin bars placed side by side so as to form compound magnets of variously shaped sections but with plane ends; the magnetic moments of these magnets diminished about 33 per cent. on lying aside for a period of eighteen years.

The rate of diminution of magnetism in different kinds of steel, with annealing, time, and temperature, is at present under investigation in this laboratory. In connection with this investigation, further experiments are being made on the same kind of steel as is referred to in this paper, and it is hoped that further results will be ready for publication at an early date. I will now give a tabular view of the results obtained up to this point. 
Annealing on the Magnetio Mmnents of Steel Magnets. 431

\begin{tabular}{|c|c|c|c|c|c|}
\hline $\begin{array}{l}\boxminus \\
! \\
\vdots\end{array}$ & $\begin{array}{l}-1 \\
\vdots \\
\vdots\end{array}$ & 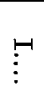 & \multicolumn{3}{|c|}{ 䒴焉 } \\
\hline $\begin{array}{l}-1 \\
\stackrel{8}{8}\end{array}$ & 莳 & 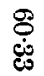 & \multicolumn{2}{|c|}{ Mag. mom. } & \\
\hline$\stackrel{\infty}{\stackrel{\leftrightarrow}{*}}$ & $\dot{\infty}$ & சं & 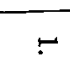 & \multirow{2}{*}{ 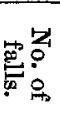 } & 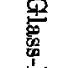 \\
\hline $\overrightarrow{\dot{0}}$ & $\dot{8}$ & ji & مبِ & & 点 \\
\hline $\begin{array}{l}\mathrm{G} \\
\mathrm{G} \\
\mathrm{G}\end{array}$ & $\begin{array}{l}10 \\
80 \\
8\end{array}$ & $\overrightarrow{\mathrm{G}}$ & \multicolumn{2}{|c|}{ Total loss. } & \\
\hline 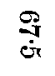 & 勇 & $\begin{array}{l}\text { : } \\
\stackrel{8}{6} \\
\dot{0}\end{array}$ & \multicolumn{2}{|c|}{ Mag. mom. } & E \\
\hline บ] & 焉 & $\overrightarrow{\dot{\theta}}$ & 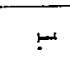 & \multirow{2}{*}{ 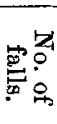 } & 它劳 \\
\hline$\vec{g}$ & $\ddot{8}$ & $\dot{\infty}$ & ب & & م: \\
\hline$\stackrel{\leftrightarrow}{\stackrel{\leftrightarrow}{*}}$ & 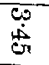 & $\begin{array}{l}\dot{10} \\
\dot{\infty} \\
\not\end{array}$ & \multicolumn{2}{|c|}{ Total loss. } & ర్ \\
\hline $\begin{array}{l}\stackrel{8}{B} \\
\stackrel{B}{*}\end{array}$ & 총 & 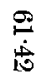 & \multicolumn{2}{|c|}{ Mag. mom. } & 帘 \\
\hline 峁 & $\begin{array}{l}10 \\
\dot{\omega}\end{array}$ & $\overrightarrow{8}$ & 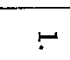 & \multirow{2}{*}{ 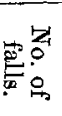 } & 总总 \\
\hline 芯 & $\overrightarrow{\dot{山}}$ & $\overrightarrow{\dot{0}}$ & $\varphi$ & & $0^{0}$ \\
\hline$\stackrel{\infty}{\dot{\oplus}}$ & ن. & $\begin{array}{l}10 \\
\dot{10} \\
\stackrel{0}{+}\end{array}$ & \multicolumn{2}{|c|}{ Total Loss. } & $\stackrel{9}{\stackrel{9}{5}}$ \\
\hline $\begin{array}{l}\stackrel{g}{i} \\
\dot{g}\end{array}$ & $\begin{array}{l}\mathscr{D} \\
\infty \\
\dot{0} \\
\stackrel{0}{\pi}\end{array}$ & 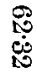 & \multicolumn{2}{|c|}{ Mag. mom. } & $F$ \\
\hline 晃 & $\begin{array}{l}\dot{0} \\
\dot{9}\end{array}$ & $\stackrel{9}{\dot{\Xi}}$ & $\leftarrow$ & \multirow{2}{*}{ 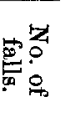 } & 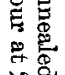 \\
\hline$\dot{g}$ & 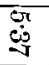 & $\begin{array}{l}\infty \\
\dot{d}\end{array}$ & ب̣ & & 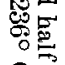 \\
\hline $\begin{array}{l}\vec{\infty} \\
\stackrel{\Xi}{\Xi}\end{array}$ & 点 & $\stackrel{\dot{\delta}}{\Phi}$ & \multicolumn{2}{|c|}{ Total loss. } & \\
\hline $\begin{array}{l}\stackrel{\pi}{0} \\
\dot{\theta}\end{array}$ & $\begin{array}{l}g \\
g \\
\dot{0}\end{array}$ & $\begin{array}{l}\stackrel{8}{8} \\
\dot{8}\end{array}$ & \multicolumn{2}{|c|}{ Mag. mom. } & 总 \\
\hline $\begin{array}{l}\vec{y} \\
\dot{\sigma}\end{array}$ & 品 & 8 & +- & \multirow{2}{*}{ 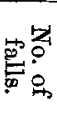 } & 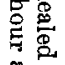 \\
\hline$\overline{\dot{\infty}}$ & $\vec{N}$ & $\dot{0}$ & ب & & 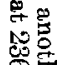 \\
\hline $\begin{array}{l}\mathscr{8} \\
0 \\
0\end{array}$ & $\begin{array}{l}15 \\
0 \\
0\end{array}$ & فे & \multicolumn{2}{|c|}{ Total loss. } & \\
\hline 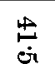 & $\stackrel{\leftrightarrow}{\stackrel{\leftrightarrow}{J}}$ & $\begin{array}{l}\qquad \infty \\
0 \\
0\end{array}$ & \multicolumn{2}{|c|}{ Mag. mom. } & 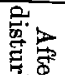 \\
\hline$\dot{\overrightarrow{\dot{F}}}$ & $\overrightarrow{\mathrm{d}}$ & $\dot{8}$ & $\leftarrow$ & \multirow{2}{*}{ 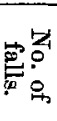 } & $\begin{array}{l}\frac{0}{2} \\
\end{array}$ \\
\hline $\overrightarrow{\dot{\omega}}$ & $\vec{\infty}$ & 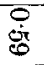 & مث & & $\begin{array}{c}00 \\
0 \\
30\end{array}$ \\
\hline 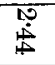 & $\begin{array}{l}\dot{\omega} \\
\dot{\Phi} \\
\dot{\phi}\end{array}$ & $\vec{\sigma}$ & \multicolumn{2}{|c|}{ Total loss. } & 总吉 \\
\hline
\end{tabular}

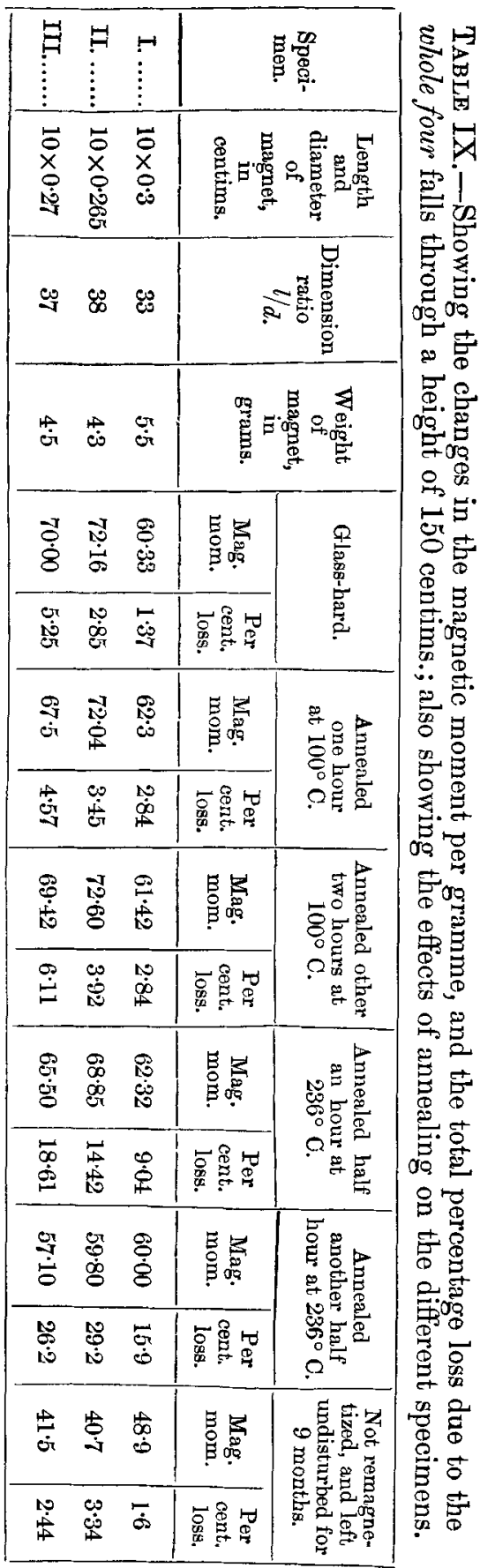


Mr. Bottomley's modification of the air-thermometer, referred to above, which was used for measuring the high temperatures, is constructed and employed as follows:-

Suppose a glass tube, $\frac{1}{2}$ inch or $\frac{3}{4}$ inch internal diameter, is made to the shape shown in fig. 1 , which is a quarter of the full size of the tubes used in these experiments.

The parts $A B$ and $D C$ are drawn out to fine capillary tubes, very small in volume in comparison with the bulb $\mathrm{BD}$ of the thermometer. When ready for use it is completely filled with pure dry air and closed at $\mathrm{C}$, but open at $\mathrm{A}$.

The parts CDB and the greater portion of $A B$ are now inserted into the liquid, the temperature of which we wish to measure; and when it has been in long enough to be at the same temperature as the liquid, it is sealed at $A$ with a blowpipe flame, thus enclosing a sample of the air at the required temperature. The height of the barometer at the time of closing is also noted.

Fig. 1.

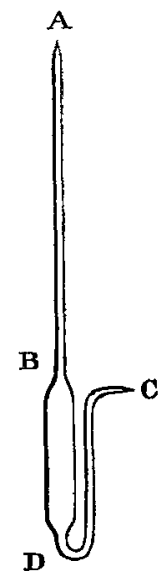

It is then taken out and allowed to cool, and also thoroughly cleaned, with alcohol if the bath has been of oil, as it was in the case under consideration.

It is now carefully weighed in a chemical balance; then the end $\mathrm{C}$ is opened under water at a known temperature; the height of the barometer being again noted.

By this operation the water is allowed to rush into the bulb $\mathrm{BD}$ and to compress the contained air to the volume consistent with the barometric height and temperature at the given instant.

The thermometer with the contained air and water is again carefully weighed, at the same time taking care to add the small piece of tube which was broken off in the act of opening the end $C$. The remaining part of the tube $A B$ is now filled with water by breaking off the end $A$, and the whole again carefully weighed.

In the following calculation the weight of the air displaced during this last operation is assumed to be so very small that for our present purpose we may neglect it.

Let now

$g=$ Weight of the glass, in grammes.

$g+w_{1}=$ Weight of the glass and the contained air, in grammes.

$g+w_{2}=$ Weight of the glass and water, in grammes.

$t=$ Temperature of the water employed. 
Assumptions required for the Proof of Avogadro's Law. 433

$\mathrm{T}=$ The absolute temperature of the oil-bath.

$\mathrm{H}=$ Observed barometric height at the time of sealing.

$\mathrm{H}^{\prime}=$ The barometric pressure at the time of opening, corrected for pressure of vapour of water, at the

Then we have temperature of the water used in filling the tube.

$$
\begin{aligned}
& \frac{\mathrm{H}^{\prime}}{\mathrm{H}} \times \frac{w_{2}-w_{1}}{w_{2}}=\frac{273+t}{\mathrm{~T}}, \\
& \therefore \mathrm{T}=\frac{\mathrm{H} w_{2}(273+t)}{\mathrm{H}^{\prime}\left(u_{2}-w_{1}\right)} .
\end{aligned}
$$

In these experiments the observed values were, after making all corrections,

Hence

$$
\begin{aligned}
\mathrm{H} & =752 \cdot 4 \text { millim. } \\
\mathrm{H}^{\prime} & =744 \cdot 8 \text { " } \\
w_{2} & =5 \cdot 310 \text { grammes. } \\
w_{1} & =2 \cdot 278 \quad " \\
t & =15^{\circ} \mathrm{C} .
\end{aligned}
$$

$$
\mathrm{T}=\frac{752 \cdot 4 \times 5 \cdot 31 \times 288}{744 \cdot 8 \times 3 \cdot 032}=509 \text {. }
$$

And the temperature of the oil was therefore $509-273=$ $236^{\circ} \mathrm{C}$.

L. The Assumptions required for the Proof of Avogadro's Law. By Professor TAIT*

TWWO months ago (in consequence of a chance hint in 'Nature') I managed to procure a copy of Prof. Boltzmann's paper (antè, p. 305), and inserted a reply to it in the (forthcoming) Part II. of my investigations ; but, as there may be some delay in the publication, I send a short abstract to the Philosophical Magazine.

Prof. Boltzmann says that I do not expressly state that my work applies only to hard spheres. 'This is an absolutely unwarrantable charge, as I have taken most especial care throughout to make this very point clear.

Prof. Boltzmann, while objecting to my remark about "playing with symbols," has unwittingly furnished a very striking illustration of its aptness. His paper bristles throughout with formulæ, not one of which has the slightest direct bearing on the special question he has raised!

$\mathrm{He}$ asserts that, in seeking a proof of Clerk-Maxwell's Theorem, I have made more assumptions than are necessary. To establish this, he proceeds to show that the Theorem can

* Communicated by the Author.

Phil. Mag. S. 5. Vol. 23. No. 144. May 1887. $2 \mathrm{G}$ 